\title{
Bilgi Politikaları Açısından Kapitalist Ekonomik Sistemde Bilgi Toplumu Olgusu
}

\author{
Information Policies of Information Societies in the Realm \\ of Capitalistic Type of Economic Systems
}

\section{Tülay Fenerci*}

\begin{abstract}
Öz
Çağımızın yeni olgusu bilgi toplumu, bilgi ve bilgi teknolojilerinin üretim araçları arasına girmesi ile gerçekleşen yeni bir ekonomik, sosyal ve siyasal evreyi temsil etmektedir. Bu olgu, kapitalist sistem içinde gelişmekte ve yayılmaktadır. Hem kapitalist sistemin hem de bilgi toplumunun özellikle gelişmekte olan ülkeler açısından sunduğu fırsatlar yanında taşıdığı riskler de bulunmaktadır. Söz konusu fırsatlardan yararlanmak ve riskleri en aza indirgemek, doğru formüle edilmiş bilgi politikaları ile mümkün olabilir. Bununla beraber bilgi politikaları sadece altyapı sorunu çerçevesinde değerlendirilmemelidir.
\end{abstract}

Anahtar sözcükler: Bilgi toplumu, Bilgi politikaları, Kapitalizm.

\begin{abstract}
The age of information society represents a new economic, social and political era where information and information technologies are among primary instruments of production. Actually the mentioned societal
\end{abstract}

* Yrd.Doç.Dr.; Ankara Üniversitesi DTCF Bilgi ve Belge Yönetimi Bölümü 06100 SıhhiyeAnkara (tfenerci@ttnet.net.tr). 
characteristics flourish in the capitalist economic system. Both the capitalist system in itself and information society offer opportunities and consist challenges especially for developing countries. In order to get benefit from opportunities and reduce risks, the information policies should be formulated rationally. However the information policies should not be asserted only as a problem of implementing infrastructure.

Keywords: Information society, Information policies, Capitalism.

\section{Giriş}

Çağımızın yeni olgusu olan "bilgi toplumu", aslında ekonomik bir dönüşümü ifade etmektedir. Ekonomik dönüşümü tetikleyen bilgi teknolojileri (bilgisayar ve iletişim teknolojileri) ise bilginin bir servet yaratma aracı olarak yükselen bir değer haline gelmesine katkıda bulunmuştur. Bilgi tabanlı ekonomik dönüşüm, yaygın bir ekonomik sistem olan kapitalizm bünyesinde gerçekleşmektedir. Kapitalist sistemin özgül özellikleri ile hareket yasalarının yeni ekonomik ve toplumsal yapının şekillenmesinde temel rol oynayacağı kuşkusuzdur. Ne var ki bugüne kadar kapitalist sistemin ortaya çıkış, gelişme ve yayılma evrelerinde önemli sosyal sorunlar da yaşanmıştır. Buna paralel olarak yeni toplumsal yapılanmayı ifade eden bilgi toplumunda da, benzer sosyal sorunların yaşanma riski vardır. Bilgi teknolojilerinin sunduğu olanaklar, sosyal sorunlara yönelik çözümlerin üretilmesi ve risklerin azaltılması bağlamında önemli fırsatlar olarak değerlendirilebilir.

Anılan teknolojilerin yüksek performanslı olması ve bağlanabilirliği sağlaması önemli faktörler olmakla beraber erişim eşitliğinin gözetilmesi, erişim bilgi ve becerilerinin kazandırılması ve insanların yaşam kalitesini yükseltecek, 
onların gereksinimlerine yanıt verebilecek içerik, kapsam ve düzeyde bilginin sunulması, üzerinde önemle durulması gereken konulardır. Bunun yanında bilginin elde edilebilir kıınması, dağıtımı ile işınmesini gerçekleştiren her türlü sistem ve kanalın işlevsel hale getirilmesi gerekmektedir.

O nedenle bilgi toplumu olgusunu, yalnız üretimde verimliliği artırma ve altyapı oluşturma çerçevesinde ele almak, yeterli bir kavrayış olmayacaktır. Dolayısıyla bilgi politikaları oluştururken bireylere yeni toplumsal yapının öngördüğü nitelilikleri kazandıracak konulara da yer verilmesi gerekmektedir.

$\mathrm{Bu}$ bağlamda yazıda, kapitalizmin ortaya çıktığı koşullara yer verilerek sistemin özgül özellikleri ve hareket yasaları açıklanmış, bilgi toplumuna dönüşümün bu sistem temelinde geliştiği varsayımıyla bilgi toplumu ve kapitalist sistem ilişkisi kurulmaya çalışılmıştır. Bunun yanısıra kapitalist sistemin toplumsal açıdan barındırdığı olumsuzlukların bilgi toplumuna taşınmaması için, oluşturulacak bilgi politikalarında yer verilmesi gereken konulara dikkat çekilmek istenmiştir.

\section{Kapitalizmin Ortaya Çıkışı}

Ekonomik bir sistem olan kapitalizmin özgül özelliklerini anlamak açısından onun hangi tarihsel koşullarda ortaya çıktığını bilmek önemlidir.

Kapitalizmin kökenine ilişkin öne sürülmüş birçok görüş bulunmaktadır. Ancak bunlardan en yaygın olarak bilineni, kapitalizmi "ticarileştirme modeli”nin bir uzantısı olarak gören görüştür. Bu görüşe göre, kapitalizm neredeyse insanlık tarihi kadar eskidir; zaten hep varolmuştur. Çünkü insanların takas, mübadele ve değişime doğal eğilimleri vardır ve bireyler rasyonel olarak kendi çıkarları doğrultusunda değişim eylemi içinde bulunurlar. Söz konusu eylemler üretim araçlarındaki teknik ilerlemeler, gelişen işbölümü ve artan uzmanlık eşliğinde gelişerek süreklilik arz etmiştir. Bu yaklaşım kapitalizmi, ticaretleştirme modelinin bir sonucu olarak değerlendirmekte ve kapitalizmin ilerlemesini, siyasal ve kültürel baskılardan kurtulmasına yani ticari fırsatların genişletilmesine bağlayarak açıklamaktadır. Söz konusu kısıtlamalar ise yalıız Batı'da kaldırılmıştır. Anılan yaklaşımda ticarileştirme modelinin, feodalite döneminde kesintiye uğradığı varsayılır. Henri Pierenne, bu varsayımı şöyle açıklar: Doğu ile Batı arasındaki Akdeniz ticaret yolu Müslümanların istilası ile kapatılmış ve eski ticari sistemin gelişmesi engellenmiştir. Daha sonra 
Avrupa'da kentlerin büyümesi ve tüccarların özgürleşmesiyle ticaret yeniden canlanmıştır $^{1}$ (Wood, 2003, ss. 19-21; Tanilli, 2002, ss. 64-66).

Yukarıda sunulan yaklaşım doğrultusunda ticarileştirme modelinde yaygın olan iki temel varsayım vardır. Bunlardan ilki, kapitalizmin "kent" ile birleştirilmesidir. Kent başlangıcından beri kapitalizmi bünyesinde barındırmaktadır. Yine Piernne'ye göre kentler, erken modern dönemde görülmemiş bir bağımsızlıkla ortaya çıkmıştır ve kendilerini ticarete adayan kentliler (burjuva sınıfı) kısa zamanda kenti egemenlikleri altına almışlar, teknolojideki ilerleme ve kent ekonomisinin özgürleşmesinin ardından, ticari rasyonalitedeki sınırlamalar da kaldırılınca modern kapitalizm doğmuştur (Wood, 2003, s. 21). Diğer bir varsayım, ilkini destekler biçimde kapitalizmin, burjuvazi ile birleştirilmesidir. Peki burjuva kimdir? Fransızca'daki kullanım biçimiyle burjuva, geçimini sağlamak için el ya da bedeni yerine aklını kullanan (aynı zamanda entelektüel) ve soylu olmayan kentlidir. Burjuvazi ve kapitalizm terimlerinin birbirine yaklaşması, kent sakininin tüccarlaşarak kapitalistleşmesi sürecinde izlenebilir (Wood, 2003, s. 22).

Sonuç olarak bu yaklaşım, zaten hep varsaydığı kapitalizmin kimi zaman kesintiye uğrasa da, üretici güçleri geliştirerek sürdürülen ekonomik bir büyüme süreci olarak ilerlediğini, çünkü piyasanın mantığının değişmediğini varsaymaktadır.

Ticarileştirme modeli ile birçok ortak yanı bulunan dünya sistemleri teorisine göre kapitalizm, geniş ticaret ağlarının dünyayı sardığı erken modern

\footnotetext{
${ }^{1}$ Karolanj Imparatorluğu’nun kurduğu merkezi yapılanmanın yerini alan yeni siyasal, ekonomik ve toplumsal düzenin egemen olduğu 10-12. Yüzyıllar arasındaki döneme feodalite denmektedir (Thema Larousse, 1994, s. 96). Islamiyetin yayılmasına bağlı olarak Akdeniz ticaretinin gücünü ve etkinliğini yitirmesi, Baltık ticaret yolları ile Doğu ırmakları üzerinden yapılan ticaretin canlanmasına neden olmuştur. Bu gelişmelerden Slav dünyasına giderek yerleşen ve Bizans ile Bağdat'la düzenli ilişkiler kuran Isveçliler yararlanmıştır (Thema Larousse, 1994, s. 82). 1161'de kurulan ve 12. Yüzyıl'da örgütlenen Hansa Birliği sayesinde Kuzeyde ve Italyanlar sayesinde de Güneyde ticaret trafiği canlanmıştır (Thema Larousse, 1994, s. 103).
} 
dönemdeki dünya ekonomisi bağlamında ortaya çıkmıştır. ${ }^{2}$ Avrupa'nın dışında ticari ve teknolojik olarak kendinden daha ileri bir dünya vardır. Bu dengesizlik ileri uygarlıkların zenginlik birikimini eşitsiz değişim ve emperyal sömürü aracılığı ile engellemiş ve bundan yararlananlar elde ettikleri birikimi yatırıma sokarak kapitalizme ve özellikle de onun sanayi biçimine geçmeyi gerçekleştirmiştir (Wood, 2003, s. 27).

Kapitalizmin kökenine ilişkin öne sürülen bu yaygın görüşlere Wood eleştirel yaklaşmakta ve köken tartışmasına farklı bir açıklama getirmektedir. O'na göre ticaret ekonomisi ile kapitalist ekonomi arasında "piyasa zorunlulukları" ile "mülkiyet ilişkileri" açısından temel farklılıklar vardır.

Ticaret toplumunda kent, piyasa işlevini görür. Ama buradaki mübadele "piyasa fırsatları"na dayanmaktadır. Yani ticarette temel işleyiş, bir malı piyasadan ucuza alıp diğerinde pahalıya satarak kâr elde etmek şeklindedir. Bu işleyiş, üretimde rekabet yaratıcı ve dönüşüme zorlayıcı nitelikte değildir. Bunun yanı sıra emek üretkenliğini kesintisiz artırmaya zorlayıcı bir işleyiş de değildir. Kârın ölçüsünü belirleyen, yerel ya da bölgesel uzmanlaşmadır. Kâr maksimizasyonu baskısı yoktur. Rekabet daha çok taşımacılıktaki üstünlük, ulaşım yollarına ve denizlere egemen olmak ve tekelci imtiyazlara sahip olmakla yani dolaşım avantajlarıyla ilgilidir. Bütün kapitalist ekonomiler ticarete dayanır ama ticarete dayalı bütün ekonomiler kapitalist değildir (Weinberg, 2002). Ne var ki bu işleyiş kapitalist olmayan sömürü biçimiyle beraber yürümektedir. Bununla beraber sömürgecilik, Batı Avrupa'da birikim yaratmış olsa da kapitalizm, sömürgecilikte öncü rol oynayan ve bundan yüksek fayda sağlayan İspanya ve Portekiz gibi ülkelerde ortaya çıkmamıştır. Ne

${ }^{2}$ Geniş ticaret ağlarının kurulması, coğrafi keşiflerin sonucudur. Bu keşiflerin ekonomik ve dini nedenleri vardır. 14. Yüzyıl'la beraber Avrupa'nın altın yatakları tükenmiştir. Oysa Afrika'da altın madenleri olduğu bilinmektedir. (Daha önce Araplar Sudan'daki altın madenlerine ulaşmışlardı). Öte yandan Uzakdoğu'dan gelen baharata gereksinim vardır. Ama Akka'nın 1291'de Müslümanların eline geçmesi ile bu yol Batı'ya kapanmıştır. Anılan durumlar, Doğu'ya ulaşmak için yeni yolların arayışına yönelinmesine neden olmuştur (Thema Larousse, 1994, s. 128). Sonuçları ise; Avrupa'ya değerli madenler akmıştır. Yeni kaynakların işletilmesi, kumpanya diye adlandırılan özel şirketlere emanet edilmiştir. Her ülkede bir Hindistan Kumpanyası kurulmuştur. Bunlar bir çeşit devlet içinde devlet olmuştur. Köle ticareti başlamış, yeni gıda maddelerinin girişi ile tüketim alışkanlıkları değişmiş ve dünya hakkında edinilen yeni bilgilerle, yeni düşünce ve yaşam tarzları ortaya çıkmıştır (Thema Larousse, 1994 , s. 130). 
üretici, ne de artık'a (üretim fazlasına) dolaylı yoldan (vergilendirme) el koyan egemen sınıf, piyasaya bağımlı değildir. Floransa ve Hollanda Cumhuriyeti ticaret toplumunun en güzel örnekleri olmalarına rağmen, kapitalizmin doğuşu buralarda değil, İngiltere'de olmuştur. Çünkü Ingiltere'de hem üreticileri, hem de artık'a el koyanları indirgenemez biçimde rekabetçi üretime bağımlı kılan farklı toplumsal mülkiyet ilişkileri rekabet, düşük maliyetli üretim, kâr maksimizasyonu, artık'ın yeniden yatırıma sokulması ve üretici güçlerin geliştirilerek sistematik bir şekilde emek üretkenliğinin artırıması yönündeki amansız bir zorlamayı harekete geçirerek kapitalizmi doğurmuştur (Wood, 2003, s. 105). O halde söz konusu dönüşüm neden Ingiltere'de meydana gelmiştir?

Bu dönüşümün odağında mülkiyet ilişkilerindeki dönüşüm yatmaktadır. Söz konusu dönüşümü hazırlayan koşulların tarihsel süreç içindeki gelişimi Ingiltere'de diğer Avrupa monarşilerinden farklı biçimde gerçekleşmiştir. Koşulların olgunlaşma sürecinde belirleyici rol oynayan bazı temel faktörler söz konusudur. Bunlardan biri, devletin merkezileşmesidir. ${ }^{3}$ Diğer bir faktör, siyasi yönetimin örgütlenme biçimi ve işleyişidir. Idari sistem, hem merkezi hem de yerel bir yönetim biçiminde yapılandırılmışıır ${ }^{4}$. Ayrıca güçlü bir maliye ve adalet sistemi vardır. 13. Yüzyıl'dan 16. Yüzyıl'a kadar geçen zamanda devlet ve siyasi yapı güçlenmiştir.

Anılan faktörler mülkiyet ilişkilerinin değişimini yaratan koşulların oluşumuna zemin hazırlamıştır. Devletin merkezileşmesi ile topraklar da merkezi-

\footnotetext{
3Ingiltere'nin, feodalitenin parçalı yönetim düzeninden merkezi devlete geçişi diğer Avrupa monarşilerinden daha etkili biçimde gerçekleşmiştir. Fransa'daki feodal düzeni Ingiltere, Iskoçya ve Irlanda'ya taşıyan Norman Krallarından I. William, 1066'da fethettiği Anglo-Saksonlara ait bütün toprakları Norman soylularına dağıtarak feodal bir hiyerarşi kurmuştur. Bu soylular birkaç köyden oluşan geniş topraklar üzerinde manor denilen malikaneler kurmuşlardır. Kralın bu sisteme göre bağış isteme, vergi toplama, orduyu görevine çağırma ve veraset haklarını denetleme gibı yetkileri vardır. Ilerleyen zamanda soylu baronlar Kralın yetkilerini kullanırken meclis kararlarına, ülke geleneklerine ve vassalların özgürlüklerine uymasını sağlamak amacıyla komün birliğini kurdular ve 1215'te Magna Carta'yı Kral'a imzalattılar. Bu direniş, Kral'ın yetkilerini sınırlandırarak devletin yönetiminde köklü değişikliğe neden olmuş ve modern devletin doğmasına yol açmıştır (Thema Larousse, 1994, s. 87).

${ }^{4}$ Merkezi yönetimin başı Kraldı ve yönetimde en büyük destekçisi Kral Meclisi, saray erkanı, din adamları ve hanedanlık üyeleriydi. Yerel yönetimin başı ise Kralın temsilcisi olan ve geniş yetkileri bulunan şeriflerdi. Aristokratlar ve yerel eşraftan seçkin kişiler ise siyasi otoriteye yönetimde yardımcı oluyorlardı (Thema Larousse, 1994, s. 86).
} 
leşmiştir. Geniş toprakların sahibi olan baronlar büyük toprakları denetimleri altında tutmaktadırlar ve bu durum, toprak mülkiyetinin yeni biçimlerde kullanılmasına olanak vermektedir. Baronlar, geniş toprakların bir kısmını kendi köylülerine işletmekte, bir kısmını da işletilmek üzere kiralayabilmektedirler. Böylelikle toprakları kiralama yoluyla işleten girişimciler ortaya çıkmıştır. Kiracılar yalnızca bir tüketici piyasası için değil, ama toprağa erişim piyasasında da rekabet etmek zorunda kalmışlardır. Dolayısıyla kiracılar yalnızca toprak sahiplerinin baskılarına değil aynı zamanda onları, üretkenliklerini geliştirmeye zorlayan piyasa zorunluluklarına katlanmışlardır (Wood, 2003, s. 111). Bunun sonucunda toprak sahibi, kapitalist kiracı ve ücretli emekçi ortaya çıkmıştır. Ücretli emeğin artışıyla emek üretkenliğini artırma baskıları oluşmuştur. Bu süreçte, tarım üretimi, tarımsal üretimle uğraşmayan büyük bir nüfusu geçindirebilen bir üretkenliğe ulaşmıştır. Bunun yanında iç piyasada hem ücretli çalışan, hem de tüketici konumda olan ve giderek büyüyen mülksüz bir kitle ortaya çıkmıştır. Ingiliz sanayi kapitalizmini oluşturan arka plan budur (Wood, 2003, s. 114).

Kiracıların toprağın işletim hakkını alabilmek için üretim araçlarına erişim piyasasında rekabet etmesi gerekiyordu. Doğal olarak piyasaya bağımlılık doğdu. Rekabet gücünü belirleyen ise üretimdeki üretkenlik artışıydı. Üretkenliği artırmanın odağında ise ıslah fikri yer aldı John Locke, ıslah'ı mülkiyet haklarının temeli olarak gösterdi. ${ }^{5}$ Yazara göre bireylerin mülkiyet hakkı, yaratabildikleri "değişim değeri"nden kaynaklanıyordu. Bu değeri yaratabilen mülkiyet hakkını kazanabilirdi (Wood, 2003, s. 169) Islah fikri, üretimde rekabeti zorunlu kıldı ve değişim değeri yaratmayanın mülksüzleştirilmesini haklı gösterdi. Bunun yanı sıra ıslah fikri çitleme ${ }^{6}$ uygulamasıyla yaşama geçirildi. Üretim araçlarına erişim için piyasaya bağımlı hale gelen ve rekabet avantajı elde

\footnotetext{
5 Siyasal düşünce tarihçilerine göre bu teoriyi ilk ortaya atan Locke değildir. Ama onun getirdiği yenilik yerel egemenin rızası olmaksızın kullanılmayan topraklara sömürenin el koymasını haklı çıkarmasıdır (Wood, 2003, s. 120). Richard Tuck, bu düşünceyi ilk ortaya atanın Thomas More (1516) olduğunu iddia etmektedir (Wood, 2003, s. 175).

${ }^{6}$ Çitleme, ortak kullanımda olan arazilerin tarıma kazandırılması ve üretimde verimliliğin arttırıması amacıyla toprak sahiplerinin arazileri çitle çevreleyerek kullanım hakkını kısıtlamasıdır.
} 
etmesi ve daha yüksek kâr sağlayabilmesi toprak miktarına ve üretim tekniklerinin gelişmesine bağıı olan toprak sahipleri ve kiracılar daha önce ortak kullanımda olan toprakların kullanım haklarının (mera kullanma hakkı gibi) sınırlandırılması için mücadele başlattılar. Bu baskıların sonucu ortaya çıkan ve mülkiyet haklarında değişim yaratan çitleme uygulaması isyanlarla karşılansa da 18. Yüzyıl'da Parlamento tarafından yasalaştırılarak meşruluk kazandı.

\section{Kapitalizmin İşleyişi ve Hareket Yasaları}

Ekonomi servet yaratan, dağıtan ve tüketen bir sistemdir. Ekonomi işbölümü ve uzmanlaşmaya dayanır. Sistemin işleyiş sürecinde neyin ne kadar üretileceği, ne kadarının nerelerde dolaşıma gireceği, tüketimin yeterli düzeyde karşılanıp karşılanamadığının nasıl belirleneceği gibi koordinasyona yönelik sorunlar vardır. Ekonomik bir sistem olan kapitalizmin unsurları ve unsurlar arasındaki etkileşim, sistemin kendine özgü hareket yasaları ile işleyerek koordinasyon sorununu çözer. Ayrıca kapitalizmde sistemin işleyişini yönetmekle yükümlü bilinçli bir otorite yoktur. Otorite, sistem içinde dağılmıştır.

Kapitalist sistemde temel unsurlar özel mülkiyet, pazar ve yasa kuralı'dır (Walberg ve Joseph, 2003, s. 83).

Bu sistemde bir kişinin yaşamı, özgürlüğü ve fiziksel olarak sahip olduğu herşey onun özel mülkiyeti olarak nitelendirilmektedir. Bir başka deyişle özel mülkiyet; kişinin, "kendisinin olan bir şeyi yasa çerçevesi içinde istediği gibi kullanabilme hakkını taşıma durumu ya da sahipliğï"dir (Türkçe sözlük, 1988). Kişinin bilgisi, emeği, yaşamı, özgürlüğü de dahil olmak üzere sahip olduğu herşey kendisinin mülkiyeti altındadır ve bu mülkiyeti denetim altında tutmak, kişinin kendi tasarrufundadır. Ancak bazı mülkiyet haklarının kişinin tasarrufunda (satılabilir, devredilebilir) olup, olamayacağı tartışma konusu olmuştur. Örneğin, özgürlük, devredilebilir, satılabilir bir mülkiyet midir? Tarihçi Richard Pipes'a göre özgürlüğün devredilemez bir mülkiyet olarak değerlendirilmesi Amerika'da köleliğin kaldıııması hareketi bağlamında ortaya çıkmış ve Hugo Crotius'un 1625'te yazdığı "On the Law of War and Peace" adlı eserinde ele alınmıştır (Walberg ve Joseph, 2003, s. 90).

Öte yandan Ingiliz düşünür John Locke ise 1690 tarihli eseri, "Two Treaties on Civil Government' da kişinin kendisi üzerindeki mülkiyetini onun serveti olarak değerlendirmekte ve kişinin özgürlüğünün bu mülkiyete olan 
sahipliği ile mümkün olduğunu öne sürmektedir. Bunun yanı sıra Locke, kişinin mülkiyetinin kendi tasarrufunda olduğunu ancak bedeli ödenmeden, zorla ondan alınamayacağını söylemektedir. ${ }^{7}$

Özetlenecek olursa kapitalist ekonomide kişinin serveti, onun kendi kişiliği üzerindeki mülkiyetidir. Bu mülkiyet onu hür yapar ve mülkiyetin özel sahipliği kişinin servet edinme hakkını içerir. Servetini nasıl kullanacağı kişinin kendi tasarrufundadır. Genellikle de servetini kendi çıkarları doğrultusunda kullanma eğilimindedir. Böylelikle mülkiyetin hareketi hep onu en üst seviyede kullanabilecek ellere doğrudur.

Sistemin bir diğer temel unsuru, pazar ya da piyasadır. Piyasa tarafların (üretici, tüketici) karşılıklı gereksinimleri için değişim eyleminde (ticaret) bulunduğu gönüllü, serbest bir rekabet ortamıdır. Bu alanda taraflar, fiyat ile simgelenen makul bir noktada değişim eylemini gerçekleştirirler. Taraflar arasındaki güç dengeleri doğal süreçler olarak işler. Örneğin, maliyetin çok üzerinde kâr elde etme eğiliminde olan üretici karşısında tüketici, gereksinimleri için kendi alım gücüne uygun fırsatlara doğru yönelir. Bu da üreticinin fiyatları daha düşük seviyeye indirmesi yönünde baskı yaparak fiyatları tüketicinin ödemeye istekli olduğu seviyeye çeker. Bu bağlamda fiyatlar, taraflar arasındaki güç dengelerinin değişimi hakkında bize bilgi verir. "Üreticiler ve tüketiciler arasındaki rekabet, girişimcilerin elde ettiği kârı ve tüketicilerin ödediği fiyatı, üreticinin ürünü üretmek için kabul edebileceği en alt seviyeye çekme eğilimindedir” (Walberg ve Joseph, 2003, s. 90). Burada girişimci, kaynakları daha iyi biçimde kullanıma sokarak kâr sağlama amacında olan, fırsatlara duyarlı ve risk alabilen kişidir. Girişimcinin hareketi kâr potansiyeli olan işlere doğrudur ve yatırımların yeni üretim alanlarına girmesini sağlar.

Bir diğer unsur olan yasa kuralı mülkiyet hakları, vatandaşlık hakları ve görevlerini içerir. Vatandaşlar ve kuruluşlar arasındaki anlaşmazlıklarda dev-

\footnotetext{
${ }^{7}$ Ne var ki Locke, mülkiyet hakkının kişisel özgürlükten ayrı tutulamayacağını söylemesine rağmen değişim değeri'ne yönelik açıklamasıyla (değişim değeri yaratamayanın mülkiyeti bedeli ödenerek alınabilir) dikkate alınırsa, mülkiyete el koyma hakkını, vicdani ve etik olarak uygun hale getirdiği sonucu çıkarılabilir. Aslında bu anlayış Locke'dan daha önce avukat Sir John Davies'in Irlanda'nın durumu hakkında Salisbury Kontuna yazdığı mektupta da görülmektedir (Wood, 2003, s. 172).
} 
let, yasaları ve mahkemeleri aracılığıyla sorunları çözümleme işlevini üstlenmiştir. Hak ve ödevler konusunda sınırlılıkları belirleyen yine devlettir. Bu anlamda Locke'un da dediği gibi devletin görevi, vatandaşlarının mülkiyet haklarını korumaktır. 8

Kişisel mülkiyet, piyasa ve yasa kuralının keşfedilmesi Adam Smith'e (1723-1790) göre devlet yönetimine gereksinim olmadan bir ekonomi yaratır. "Kişiler anamallarını kendilerine en verimli olabilecek biçimde kullanırlar. Kamu yararına geliştirmek niyetinde olmadıkları gibi kamu yararına nasıl geliştirildiğini de bilmezler. Ama kendi çıkarlarını geliştirmeye çalışırken gizli bir el, niyetleriyle ilgili olmayan amaçlara hizmet etmelerini sağlar. Kendi çıkarlarını kovalarken toplumun çıkarlarını da korumuş olurlar" (Hançerlioğlu, 1977b, s. 87). Ancak, bugün birçok ülke güç ve refahın topluma dağıtılmasında devlet müdahalesini gerekli görmekte ve uygulamalarını bu yönde gerçekleştirmektedir.

Özetle kapitalist sistemde üreticiler ve girişimciler, kâr vaat eden yatırımlara yönelirken kendi çıkarlarını düşünmektedir. Ne var ki kâr vaat eden yatırım alanları aynı zamanda tüketicilerin karşılanmamış gereksinim alanlarıdır. Tüketiciler ise gereksinimlerini karşılarken alım gücüne göre kendine en yüksek değeri verene doğru hareket eder. Üretici tüketicinin hareketini kendi yönüne çevirmek için diğer üreticilerle rekabet etmek zorundadır. Daha düşük maliyetle daha kaliteli mal ya da hizmet üretebilmek için de kendi iç yapısında verimlilik ve yenilikçiliği sürekli olarak canlı tutmak zorundadır. Dolayısıyla kapitalist sistemin işleyişinde piyasa temel unsurdur. Piyasa bu alanda faaliyet gösteren ya da aktif olan aktörler arasındaki etkileşim ve ilişkileri, kendine özgü rekabet ilkeleri ve hareket yasaları ile düzenler. Doğal süreçlerin işleyişinde belli bir otorite müdahalesine gerek duymaz. Devletin işlevi sistemde adalet mekanizmasını işletmek ve yasa kuralı olan eşitlik ilkesinin uygulanmasını sağlamaktır. Özel mülkiyet hakkı sistemin, birey odaklı olduğunun bir ifadesidir. Bireylerin hak ve görev alanlarının belirlenmesi ve güvence altına alınması sistem içindeki hareketlerin ve gelişimin izlen-

\footnotetext{
${ }^{8}$ Thomas Hobbes (1588-1679) ve John Locke (1623-1704), devletin görevini insanlar arasındaki anlaşmazlıkları çözmek olarak tanımlarlar ve onlara göre otoriteye bağlıık ile varolabilirler. (Hançerlioğlu, 1977a, s. 195).
} 
mesini sağlar. Bu sistemdeki en temel özellik üretim araçlarına erişimin piyasaya bağlanmasıdır. Bu durum, piyasa zorunluluklarını yaratmıştır. Piyasa zorunlulukları, üretici üzerinde üretici güçleri geliştirme yoluyla üretkenliği artırma baskısı yaratarak üretim araçlarına erişmede rekabeti gerekli kılmıştır. Tarihsel süreç içinde üretim araçları, üretim biçimleri sınıf yapıları, mülkiyet hakları, devlet müdahalesi vb. nitelik ve nicelik açısından gelişerek bugüne gelmiş olmasına karşın ve buna paralel olarak anılan unsurların dayandırıldığı düşünsel kavrayışlar, yaklaşımlar değişime uğramış olmasına rağmen sistemin işleyişindeki hareket yasaları aynı kalmıştır. Yalnız bu, sistemin girdiği her ülkede aynı görünüşü sergilediği ve aynı biçimde geliştiği anlamına gelmemelidir. Örneğin, bugün dünyanın en güçlü ekonomilerinden birine sahip olan ABD'de imalatla birlikte gelişen kapitalizm, daha çok kolonicilik, kölelik ve şiddete dayalı sınıf mücadeleleri üzerine yükselmiştir (Weinberg, 2002). Bunun yanında Amerikan endüstrileşmesi iş ortaklığı (coorporation) biçimindeki örgütlere dayanmıştır. Söz konusu örgüt biçimini modern iş yaşamına kazandıran Amerikalıların ekonomik sisteme bir diğer katkısı ise kağıt para olmuştur.

\section{Kapitalizm ve Bilgi Toplumu}

Kapitalist bir sistemin temel unsuru ekonomik güç olarak nitelendirilmektedir. Ekonomik güç, diğerlerine gereksindikleri şeyleri vermeme gücü veya paylaşmama seçeneği ile mülkiyet eşitsizliği olarak tanımlanmaktadır. Ekonomik güce sahip olanlar ise bağımlıı̆̆ı yaratmak için baskı yaparlar. Dolayısıyla ekonomik güç kendini önce pratikte sonra yasada gösterir (Weinberg, 2002). ${ }^{9}$ Toffler ise çağımızı, "gücün değişim çağı" olarak nitelendirmekte ve bu bağlamda daha önceleri gücü temsil eden şiddet ve para gibi unsurların yerini bugün yeni bir güç unsuru olan "bilgi"nin aldığını söylemektedir. Bu bağlamda ekonomik gücün temelinde artık bilginin yer aldığı söylenebilir. Yine Toffler, gücün kendisinin iyi ya da kötü olarak nitelenemeyeceğini ancak hangi amaçla kullanılacağının onu elinde tutanların niyet ve insafına kaldığına dikkat çekmektedir (Toffler, 1992, ss. 28-29). Bu noktadan yola çıkarsak

\footnotetext{
9Weinberg'in anlatımında ifadesini bulan bu görüşler, aynı zamanda John Commans ve Thorstein Veblen ile paylaştığı görüşlerdir (Weinberg, 2002).
} 
gücün yükselen unsuru olan bilginin değişen rolünü ve "geleceğin imparatorlukları zihinlerin imparatorluğu olacaktır" diyen Churchil'in sözlerini yeniden değerlendirmemiz gerekir (Toffler, 1992, s. 25). Bilginin değişen rolünün, yeni servet yaratma sisteminin ya nedeni olduğunun ya da bu güç kaynaklarına katkıda bulunduğunun farkına varan çoğu dünya ülkeleri özellikle son on yıldır bu konuda yoğun çalışmalar içine girmişırerdir.

Bilginin, varolan ekonomik sistemlerin işleyişinde yaratacağı dinamizmin ekonomik gücü artıracağını sezen ama aynı zamanda bunun kendi ekonomileri üzerinde yaratacağı yoğun rekabet baskısını hisseden öncü ülkeler, "bilgi toplumu" sloganıyla politikalar, planlar ve programlar geliştirmektedirler. Aslında bilginin giderek ekonominin temel unsurlarından biri haline geldiğine ya da bilginin değişen rolüne ilk dikkat çeken ve bu konuda 1977 yılında ayrıntılı bir çalışma yapan Porat olmuştur. ${ }^{10}$ Porat çalışmasında düşey sektör olarak belirlediği bilgi endüstrisi ile yatay sektör olarak nitelendirdiği ekonominin diğer sektörlerindeki enformasyon etkinliklerinin tanımlamalarını yaparak ulusal zenginlikteki paylarını ölçülebilir hale getirmiştir. Böylelikle ABD ekonomisinin ne ölçüde bilgi etkinliklerine dayandığını ortaya koymaya çalışmıştır (Porat, 1977, ss. 1-14). Porat'ın çalışmasının ardından geçen yaklaşık 15 yıllık zaman dilimi, bilgi teknolojilerinin çok hızlı bir biçimde geliştiği ve yaygın kullanım alanları bulduğu bir süreç oldu. 1990'lı yıllar ise özellikle iletişim teknolojileri/ağları ve internetin potansiyel fırsatlarının farkına vararak uyanan ülkelerin bilgi altyapısını kurma, bilgi toplumu olma yönündeki çalışmalarında patlama yaşanan yıllar oldu. ${ }^{11}$

Piyasa için üretimde, rekabet esasına dayalı olarak işleyen bugünün yaygın ekonomik sisteminde, "bilgi"nin üretim araçları arasına girmesi, sistemin temel ayırıcı özelliklerinin yeniden değerlendirilmesini ve yeni kavramlarla ifade edilmesini de beraberinde getirmiştir.

\footnotetext{
10 Porat'tan önce Fritz Machlup 1962 yılında "ABD’de bilginin üretimi ve dağıtımı" adlı bir kitap yazmış ve enformasyon sektöründe çalışan insan sayısındaki artışı çarpıcı bir şekilde ortaya koymuştur (Toffler, 1992, s. 85).

${ }^{11}$ Bkz. Institute of the Information Society, 1998-2002; Global Knowledge Russia, 2002; Green Book Information Society in Brazil, 2003; Strategy and National Action Plan for the Development of the Information Society in the Republic of Bulgaria, 2002.
} 
Bir zamanlar ıslah fikrinin üretim yöntem ve tekniklerinde değişim değeri yaratma yoluyla üretkenliği artırma zorunluluğunu doğurması ve böylelikle üretim araçlarına erişimde rekabet baskısı oluşturması sonucu, piyasa zorunluluklarının ortaya çıkması gibi, bugün de bilgi (değişim değeri yaratan bir unsur olarak) odaklı üretkenliği artırma mücadelesi yaşanmaktadır.

Piyasada rekabet edebilmenin ön koşulu olan üretimde rekabet, "değişim değeri”ne dayandırılan üç unsur açısından ele alınabilir. Bunlardan ilki, mal ya da hizmet üreten "örgüt"ün kendisidir. Örgütün işleyişinde verimliliği artırma rekabetçi üretimin ön koşuludur. Verimlilik, bir çıktıyı üretirken gerekli yapısal ve işlevsel unsurların rasyonel bir biçimde yapılandırılması ve yönetilmesi anlamına gelir. İç yapılanma, temel/genel hedeflere ulaşmayı sağlayacak biçimde örgütün alt birimlerinin, kaynakların rasyonel kullanımı ve akışı bağlamında eşgüdüm ve işbirliğini gerçekleştirecek biçimde, düzenlenmesini içerir. Bir diğer konu, "yönetim"dir. Yönetim, örgütün uzun ve kısa vadeli stratejilerinin belirlenmesinde, karar mekanizmalarının geliştirilmesinde, işlevsel unsurların (insan, donanım, ara-gereç vb.) rasyonel kullanımında, işlerin yapılışında ve akışında yenilikçi, rasyonel yöntemlerin kullanılmasıyla ilgilidir. Bütün bunların odağında ise kayıtlı olsun ya da olmasın bilgi yer almaktadır. Bu bağlamda bilginin elde edilmesi, işlenmesi, dağıtılması ve yeniden kullanıma sokulması için gerekli sistem ve kanallar ile bunların yönetimi önem kazanmaktadır. Dolayısıyla örgütün kendi içinde değişim değeri yaratabilmesi için özellikle iş̧levsel unsurların verimliliğinin artırıması önceliğiyle yeni yöntem ve anlayışlar gündeme gelmekte ve buna bağlı olarak yenilikçilik, öğrenen örgüt, esnek örgüt, takım ruhu, bilgi yönetimi, enformasyon yönetimi vb. kavramlar yükselmektedir.

Değişim değerine dayandırılan bir diğer unsur, "üretim araçları"dır. Üretim araçları emek, donanım, araç-gereç, finansal kaynaklar vb.dir. Üretkenliği artırmak için anılan üretim araçlarına erişimde rekabet etmek ve eldekiler üzerinde değişim değeri yaratacak etkinliklerde bulunmak gerekir. Örneğin, emek artık yalnızca işgücünün fiziksel kapasitesini değil zihinsel potansiyelini de ifade etmektedir. Bu anlamda zihinsel kapasitenin sınırları zorlanmaktadır. Çalışanların günün gereksinmelerine uygun bilgi ve becerilere sahip olmalarının yanısıra yaratıcı, girişimci, katılımcı, öğrenen bireyler olmaları beklenmektedir. Anılan nitelikteki işgücünü çekebilmek ve varolan işgücünün yeni teknolojiler ve yeni uygulamalar bağlamında bilgi ve becerilerini yenile- 
yebilmesini sağlamak için sürekli, hizmetiçi eğitim gibi olanaklar yaratmak gerekmektedir. Bunun yanında bilgi, üretim teknolojilerine de girmiştir. Mal ve hizmet üretiminde kullanılan teknolojiler ve bilgi teknolojileri her geçen gün gelişmekte ve yansımaları yeni uygulamalar biçiminde olmaktadır. Bunun doğal sonucu olarak diğer üretim araçlarına erişimin yanında özellikle işgücü ve teknolojiye erişim ve bunlarda değişim değeri yaratma bağlamında yoğun bir rekabet baskısı oluşmaktadır.

Üçüncü unsur, "ürün"dür. Düşük maliyetli kaliteli ürün üretme tüketim piyasasında rekabet edebilme avantajı sağlar. Üründe değişim değeri yaratabilmek için üretim süreçlerinde ve yöntemlerinde yenilikçilik önem taşır. Bunun temelinde ise hem bilimsel ve teknik bilgiyi üretme ya da üretilmiş olana erişme, hem de tüketici ve pazar bilgisine erişmede rekabet baskısı vardır.

Piyasada rekabet gücünü artırmada üretkenliğin artırıması kadar mal ve hizmetlerin en uzak tüketiciye/kullanıcıya kadar ulaşması yani dağıtım ve pazarın özellikleri de önemlidir. Pazar hem tüketim alanı hem de hammadde ve enerji gibi doğal kaynakların bulunduğu alandır. Bu anlamda ticari işlemler, mal ve hizmetlerin dağıtım yolları, pazar hareketleri önem kazanmakta ve bilgi ile diğer altyapı unsurlarını geliştirilmesi gündeme gelmektedir. Böylelikle elde edilecek avantaj rekabet baskısını azaltacaktır.

Öte yandan özellikle üretkenliği artırma bağlamında toplumda potansiyel işgücünden yararlanmak için (ki burada işgücü hem tüketici hem de çalışan anlamında piyasaya bağımlıdır ve üretim araçlarına erişim için rekabet etmek zorundadır) toplumun her kesimini kapsayan olanakların/fırsatların yaratılması gerekir (tıpkı ıslah projesinde boş toprakların, bataklıkların kullanıma sokulması, tarıma kazandırılması gibi). Bu bağlamda bireyin yaşam boyu öğrenen, enformasyon okuryazarı olmaları beklenmektedir. Ancak daha önce de vurguladığımız gibi bireylerin öngörülen niteliklere sahip olabilmesi için öncelikle kendilerinde değişim değeri yaratma ve bunu sürekli kılma olanağının onlara sunulmuş olması gerekir. Bir başka deyişle toplumun her kesimine mensup tüm bireylerin bilgi teknolojilerine erişimi sağlanmalı ve buna paralel olarak bireylere değişen koşulların doğurduğu gereksinimlerle örtüşen içerikli bilgi ve programlar sunularak kazanımlarını belgeleyebilmeleri olanağı yaratılmalıdır.

Yukarıda kısaca belirtmeye çalıştığımız gibi bilgi, bilgi teknolojilerinin de desteği ile servet yaratan bir unsur haline gelmiştir. Bilgi odaklı servet yaratma kapitalist sistem içinde gerçekleştiğinden ekonomilerin işleyişindeki dönü- 
şüm (sistem farklı coğrafyalarda farklı görünüşler sergilese de) sistemin özgül özelliklerinden bağımsız düşünülemez. Bu bağlamda geleceğin bilgiye dayalı toplum yapısı en azından geçiş sürecinde bu sistem içinde gerçekleşecektir. Bilgi toplumuna geçişte erken yol alanlar kazançlı çıkacaklardır. Dolayısıyla bilgi toplumuna dönüşüm için gerekli eylemleri sistemli, koordineli ve zamanlı yürütmek önem taşır. O nedenle ülkeler kendi koşulları temelinde ve özellikleri doğrultusunda bilgi politikaları oluşturmaktadır. Bu yönde tetikleyici girişimi ABD başlatmıştır. ABD'de bilgi politikası, daha çok yüksek performanslı bilgisayar ve iletişim teknolojileri, yazılım, bilgi otoyolları ve bunları destekleyecek eğitim, araştırma ve insan kaynakları bağlamında ele alınmaktadır$^{12}$ (Türkiye Bilimsel ve Teknik Araştırma Kurumu [TÜBITAK], 2002).

Avrupa Birliği $(A B)$ ise "bilgi politikaları" terimi yerine "bilgi toplumu" terimini kullanmaktadır. Buradaki tercih, belki de dönüşümün yalnız bir altyapı sorunu değil aynı zamanda yeni bir yaşam biçimi olduğunu vurgulamak içindir.

AB'nin bilgi toplumu konusundaki politika belirleme ve eylem planları hazırlama çalışmalarında ${ }^{13}$ özellikle bilgi endüstrisinde atılım yaparak bu alandaki pazarda rekabet gücünü artırma, buna dayalı olarak sanayinin yapısını dönüştürme, ortaya çıkacak toplumsal sorunlara geniş bakış açıları getirme, toplumsal dayanışma ve fırsat eşitliğini sağlayıcı önlemler ile Avru-

12Illk başlatılan program HPCC (1991) olmuş, bu daha sonra ulusal ve ardından küresel programa dönüştürülmüş ve dünyada tetikleyici bir rol oynamıştır. Porat 1977 yılında yaptığı çalışmada, ABD'nin endüstri ekonomisi döneminde makine ve otoyolun iki temel altyapı unsuru olarak değerlendirildiğini ve ulaşımda yaşanan yoğun rekabete dayalı olarak politikasını ulaştırmanın iç sorunları doğrultusunda oluşturduğunu ve sosyal sorunların eş zamanlı ele alınmadığını ve yeni oluşumda bu konuya dikkat edilmesi gerektiğini vurgulamaşna rağmen aynı yaklaşımın devam ettiği anlaşılmaktadır (Porat, 1977, s. 207).

${ }_{13}$ Avrupa Konseyi (Commission of the European Communities), Aralık 1993 ve 24-25 Temmuz 1995 'te Korfu'da yapılacak toplantı için uzmanlarca bir rapor hazırlanmasını ister, "Europe and the Global Information Society: Recommendations to the European Council, Brussels, 1994"; Komisyon rapor doğrultusunda bir eylem planı hazırlar, "Action Plan Europe's Way to the Information Society, COM(94)347" ve 1996'da Komisyon, "Green Paper: Living and Working in the Information Society, COM(96)389" başlıklı belgeyi sunar. Belge, yüksek uzmanlar grubunu ve enformasyon toplumu forumunu enformasyon toplumunun sosyal yönleri üzerine çalışmaları için göreve çağırır ve bu grupların raporları 1997'de yayınlanır. 27 Kasım 1996'da Komisyon, Konsey'e AB'nin enformasyon toplumu bağlamında politik önceliklerinin neler olacağına dair stratejilerini ortaya koyan "Rolling Action Plan Europe at the Forefront of the Global Information Society, Final COM(96)395" adlı eylem planını sunar. 2000 yılında ise, Komisyon "e-Europe Action Plan" başıklı bir eylem planı hazırlamıştır. 
pa'nın kültürel çeşitliliğinin korunması yönünde yapılması gerekenler ön plana çıkmaktadır. Anılan politika konuları çerçevesinde AB bir eylem planı hazırlamıştır (Commission of the European Communities, 2000). Söz konusu eylem planı telekomünikasyon alanında özelleştirmeyi sağlayarak rekabet ortamı yaratmayı, iletişim ağları üzerinden verilen hizmetlerin çeşitlenmesi ve herkesçe karşılanabilir olması, herkesin internete erişim fırsatına kavuşması, internet kullanımının yaygınlaşması ve bu yönde insanların bilgi ve becerilerinin artırıması, internetin güvenli, ucuz ve hızlı olması ve internet yardımıyla devlet, sağlık, eğitim gibi hizmetlerin verilmesini yaygınlaştırma gibi eylem alanları tanımlanmıştır. Eylem planını destekleyici çalışmalar (yenilikçilik, yaşam boyu öğrenme, eğitim konulu programlar da vardır).

$A B D$ ve $A B$ başta olmak üzere hemen hemen bütün ülkeler, bilgi toplumuna dönüşümü en kısa zamanda gerçekleştirmek için yoğun çalışmalar içindeyken bu konuda henüz atılım yapmamış ya da yol almakta yavaş hareket eden ülkeler de bulunmaktadır. Bu durumun küresel anlamda yaratacağı dengesizliği önlemek ve toplumlar arasında belirgin farklılıkların onarılamaz duruma gelmeden sorunlara çözüm üretebilmek amacıyla uluslar arası düzeyde çalışmalar da yapılmaktadır. ${ }^{14}$

Bütün bu çalışmalarda değinilen ortak konular değerlendirildiğinde bilgi toplumu/bilgi politikalarında yer alması gereken konular şöyle özetlenebilir:

1- Bilgi toplumuna geçiş aslında ekonomik bir dönüşümdür. Çünkü bilgi, servet yaratma aracı olarak yeni bir rol üstlenmiştir. Bu anlamda bilgiyi değişim değeri yaratacak biçimde ekonomik, sosyal ve siyasal yaşamın tüm alanlarında kullanıma sokmak önemlidir. Dolayısıyla bilginin elde edilebilir kılınması, işlenmesi, dağıtımı, saklanması, korunması ve erişilebilmesini sağlayan eylemler ile tüm sistem ve kanallar işlevsel hale getirilmelidir.

2- Değişimi yönetebilmek için bilgiyi etkinleştiren bilgi endüstrisinin dinamik ve yenilikçi bir yapıya kavuşturulması, rekabet gücünün artırılması ve buna paralel yasal düzenlemelerin yapılması önemlidir. Bunun temelinde mülkiyet hakları, bilimsel bilgi üretimi gibi konular vardır.

\footnotetext{
${ }^{14}$ Bu konuda OECD'nin dört grup altında sürdürdügü çalışmalar ile BM ve ITU'nın ortaklaşa yürüttüğü ve bölgesel nitelikli olan "Dünya Enformasyon Toplumu Zirvesi” çalışmaları örnek olarak gösterilebilir (TÜBITAK, 2002).
} 
3- Bilgi endüstrisindeki gelişme, ekonominin diğer sektörlerindeki uygulamaları da etkileyeceğinden, bilgi toplumu politikaları mal ve hizmet üreten birçok sektörü kapsayıcı nitelikte olmalıdır.

4- Bilgi teknolojilerinin yaygın kullanımı yeni istihdam olanakları yaratmakta ve çalışma biçimlerini değiştirmektedir. Bu bağlamda çalışan ve işveren hakları, ücret politikaları, yeni işler, kaybolan işler vb. konular yasal düzenlemelerle birlikte yeniden ele alınmalıdır. Ayrıca olabildiğince çok insan kaynağını ekonomik yaşama kazandırmak, insanların bilgi ve becerilerini artırmalarına yardımcı olacak olanaklar sunmak ve topluma yaşamboyu öğrenme kültürünü kazandırmak gerekir.

5- Yeni toplum düzeninde evrensel ilke, herkesin hem bilgi teknolojilerine hem de bilgiye erişimde fırsat eşitliğine sahip olması önem taşır.

6- Insanların erişimde fırsat eşitliğine sahip olması kadar neye eriştiği de önemlidir. Bilginin kapsam, düzey, dil ve içerik açısından insanların gereksinimlerini karşılayabilecek nitelikte olması gerekir.

7- Öte yandan bir ulusun kültürel mirası, uluslararası alanda onun mülkiyetinin ve zenginliğinin en temel unsurudur. Kültürel mirasın ağlar üzerinden erişilebilir kıınması tek yönlü bilgi akışını ortadan kaldıracak ve kültürel kimliğin korunmasına katkıda bulunacaktır.

\section{Sonuç}

Yeni toplumsal yapılanma, küresel anlamda önemli fırsatlar sunmanın yanında birtakım riskler de taşımaktadır. Fırsatları olabildiğince değerlendirme ve riskleri de aynı ölçüde en aza indirgeme olanağı bulunmaktadır. Ne var ki bunu gerçekleştirebilmek yeni yapılanma olgusunu nasıl kavradığımızla ilgilidir. Bilgi teknolojilerinin sunduğu olanakları ve bilginin yararlarını görmek ve bu unsurlar üzerine odaklanmak bilgi toplumunu kavrayışta yeterli değildir. Hangi ekonomik sistem içinde bilginin, dönüşümü tetiklediği ve değişimi yönlendirdiği de önemlidir. Bu tür bir kavrayış ülkelerin kendi koşulları ve önceliklerini gerçekçi bir biçimde değerlendirmesine ve bilgi politikalarını bu yaklaşımla oluşturmalarına katkıda bulunacaktır. 


\section{Kaynakça}

Commission of the European Communities. (1994). Europe's way to the information society: Action plan (Final COM-94: 347). 10 Ocak 2002 tarihinde http://europa.eu.int/ISPO/docs/htmlgenerated/i_COM (94) 347final.html adresinden erişildi.

Commission of European Communities. (1996a). Green paper: Living and working in the information society: People first (Final COM-96: 389). 10 Ocak 2003 tarihinde http://europa.eu.int/comm/employment_social/ soc-dial/info_soc/green/green_en.pdf adresinden erişildi.

Commission of European Communities. (1996b). Rolling action plan Europe at the forefront of the global information society (COM-96: 395). 1 Ocak 2003 tarihinde http://www.europe.eu.int/information_society.htm adresinden erişildi.

Commission of European Communities. (2000). E-Europe action plan. 10 Ocak 2003 tarihinde http://www.eu.europe.int/cordis.htm adresinden erişildi.

Green Book Information Society in Brazil. (2003). 11 Şubat 2004 tarihinde http://socinfo.org.br/index.htm adresinden erişildi.

Global Knowledge Russia. (2002). 10 Ocak 2002 tarihinde http://www. globalknoweledge.ru/GKRussia/en.htm adresinden erişildi.

Hançerlioğlu, O. (1977a) Düşünce tarihi. İstanbul: Remzi Kitabevi.

Hançerlioğlu, O. (1977b) Felsefe sözlüğü. İstanbul: Remzi Kitabevi.

High-Level Group. (1994). Europe and the global information societyBangemann report: Recommendations to the European Council. 15 Kasım 2002 tarihinde http://www.ispo.cec.be/bangemann_report.htm adresinden erişildi.

High-Level Expert Group. (1997). Building the information society for all. $15 \mathrm{Kasım} 2002$ tarihinde http://www.ispo.cec.be/hleg.htm adresinden erişildi.

Information Society Forum. (1997). 15 Kasım 2002 tarihinde http://www.ispo.cec.be/info.forum/pub.htm adresinden erişildi. 
Institute of the Information Society. (1998-2002). 15 Kasım 2002 tarihinde http://www.iis.ru adresinden erişildi.

Porat, M. U. (1977). The information economy: Definition and measurement. Washington, DC: US Department of Commerce, Office of Telecommunications.

Strategy and Action Plan for the Development of the Information Society in the Republic of Bulgaria. (2002). 15 Kasım 2002 tarihinde http://www.bild.net/ispage1en.htm adresinden erişildi.

Tanilli, S. (2002). Uygarlık tarihi (8. bs.). İstanbul: Adam Yayınları

Thema Larousse: Tematik ansiklopedi insan ve tarih. (1993-1994): Cilt 1. İstanbul: Milliyet.

Toffler, A. (1992). Yeni güçler, yeni şoklar. İstanbul: Altın Kitaplar

Türkiye Bilimsel ve Teknik Araştırma Kurumu. (2002). Bilgi toplumu politikaları üzerine bir değerlendirme: Dünya ve Türkiye. 15 Kasım 2002 tarihinde http://www.bilten.metu.edu.tr adresinden erişildi.

Türkçe sözlük. (1988). Ankara: Türk Dil Kurumu.

Walberg, H. ve Joseph, L. (Ed.). (2003). Education and capitalism: How overcoming our fear of markets and economies can improve America's schools. Batt. Hoover: Institution Press. 11 Şubat 2004 tarihinde http://www.hoover.stanford.edu/courses/sgdorie/capitalism.htm adresinden erişildi.

Weinberg, M. (2002). A short history of American capitalism. 11 Şubat 2004 tarihinde http://www.newhistory.org/CH01.htm adresinden erişildi.

Wood, E. M. (2003). Kapitalizmin kökeni: Geniş bir bakış açısı. Ankara: Epos Yayınları. 